\title{
EFFECTIVENESS OF INTEGRATED CARBON CAPTURE TECHNOLOGY IN WASTE TO ENEGERY PLANTS AND IMPLEMENTATION PROSPECTS
}

\author{
${ }^{1}$ Fikri Muhammad Akbar, ${ }^{2}$ Muhammad Najmi Hafiy, ${ }^{3}$ Farid Ibrahim, ${ }^{4}$ Adam \\ Muhammad Yudhistira \\ ${ }^{123}$ Faculty of Engineering, Gadjah Mada University, Yogyakarta, Indonesia \\ ${ }^{1}$ fikri.muhammad.akbar@mail.ugm.ac.id, ${ }^{2}$ muhammad.najmi.hafiy@mail.ugm.ac.id
}

\begin{abstract}
The population in ASEAN is projected to increase to 722 million by 2030. This massive population increase had an impact not only on population quantity but also on the environment. This is reflected in the increasing number of pollution results such as waste products and carbon pollution. Waste to Energy Plants has been successful in converting waste to electrical energy by incineration, but there are still carbon emissions that has to be dealt with and on the other hand carbon pollution has been a major problem for ASEAN this past 10 years, with the data from Global Carbon Atlas showing $1671.7 \mathrm{MtCO} 2$ are emitted from the combined 10 countries in 2019. The industry categories of petroleum refineries, chemicals and others are responsible for contributing the most greenhouse gases. Analysis from the International Energy Agency shows comparison between few of the most promising solutions for carbon emission, one of them being Carbon Capture Storage (CCS). This technology captures $\mathrm{CO} 2$ that has been emitted to the atmosphere. Indonesia, the biggest country in ASEAN is also the region's most contributing country in terms of carbon emission where the CCS technology should be developed more. In this paper, the author uses a descriptive qualitative method and data reference from previous research. The results indicate that the usage of CCS is very effective to reduce the CO2 emissions emitted from Waste-to- Energy Plants with 95\% accuracy. This, in effect, will ensure effective expert knowledge communication to the general public and foster social acceptance of this technology.
\end{abstract}

Keywords: Carbon dioxide, Carbon Capture and Storage, WtE Plants, and Process Integration

DOI: $10.33541 /$ sp.v22i1.3304

Sociae Polites : Majalah Ilmiah Sosial Politik

Faculty of Social and Political Science, Universitas Kristen Indonesia

ISSN 1410-3745 print/ ISSN 2620-4975 online

Volume 22, Number 1 (Indonesia Clean Energy Conference)

Pages 30-47 


\section{Introduction}

\subsection{Background}

In ASEAN countries, waste problems is no stranger. With tremendous amount of people living within the region, necessities will increase accordingly. Recycling them has been a way to handle the situation, but there are a lot type of waste that cannot be recycled or reused, and the only way is to get rid of them. Waste to energy plants is one way to overcome the growing waste problem in our ASEAN. Waste-to-energy plants burn municipal solid waste (MSW), often called garbage or trash, to produce steam in a boiler that is used to generate electricity.

MSW is a mixture of energy-rich materials such as paper, plastics, yard waste, and products made from wood. For every 100 pounds of MSW in the United States, about85 pounds can be burned as fuel to generate electricity. Waste-to-energy plants reduce 2,000 pounds of garbage to ash weighing about 300 pounds to 600 pounds, and they reduce the volume of waste by about $87 \%$ (International Energy Agency).

However, there is still problems with waste-to-energy plants. Although it is a system leaning toward a carbon-negative environment, WtE plants still releases by product suchas $\mathrm{CO}_{2}, \mathrm{CO}, \mathrm{C}_{2} \mathrm{H}_{2}$. This gaseous products, if let loose uncontrollably, will lead to air pollution. Air pollution leads people to be exposed to fine particles in polluted air that penetrate deep into the lungs and cardiovascular system, causing diseases including stroke, heart disease, lung cancer, chronic obstructive pulmonary diseases and respiratory infections. Industry, transportation, coal power plants and household solid fuel usage are major contributors to air pollution. Air pollution continues to rise at an alarming rate, and affects economies and people's quality of life. The increasing ambition of climate targets creates a major role for technology especially in achieving carbon-neutrality in sectors presently difficult to decarbonise.

Previous studies has been conducted to find solution regarding the carbonintensive waste management production, and Carbon Capture technology have a lot of good potential in terms of fulfilling the role. Carbon Dioxide Capture and Storage (CCS) is a technology for capturing $\mathrm{CO}_{2}$ gas produced from a large-scale process, then transported to a storage location which can be located in the soil, in the sea, in carbonateminerals or used in industrial processes (Metz and Intergovernmental Panel On Climate Change.Working Group Iii 2005).

Figure 1. CCS Readiness Index Result in Several Countries

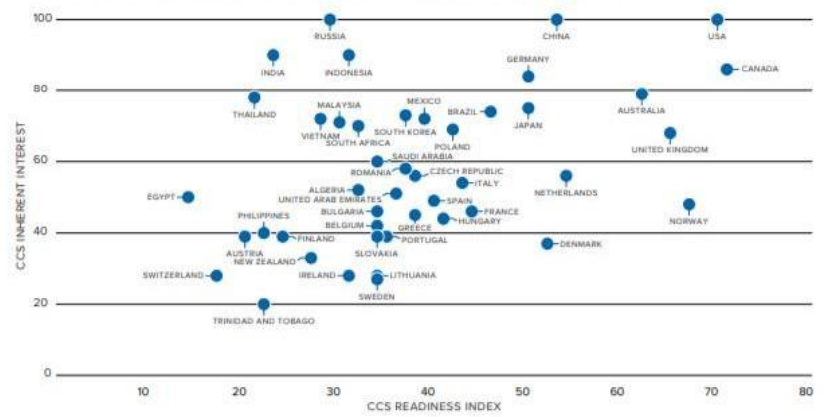

(Source: Global CCS Institute 2018)

Carbon Capture Storage is proven very promising in various technology developments. Quoting from CCS Global Readiness Index in 2018, Indonesia possess low CCS-RI scores but have high dependency on CCS deployment. Meeting emission reduction 
goals and ensuring future prosperity within a carbon-constrained world willbe impossible without immediate action. This is different compared to China, Denmark, Germany, Japan and the Netherlands. These countries have made significant advancements in CCS deployment. They are now poised to exploit CCS to meet their national climate change ambitions but some gaps in legislation, policy and/or storage resource development must be addressed before broad deployment can proceed. (CCS- GRI 2018)

\subsection{Research Question}

The questions that are being asked and tested are the following:

1. How effective are the use of CCS technology in Waste to Energy plants?

2. How is the prospects of CCS integrated WtE plants in ASEAN countries?

\subsection{Purpose and Objectives}

This study is very important to see just how urgent it is for CCS to be implemented in waste to energy plants in ASEAN countries in order to combat the current war against the overgrowing carbon emissions. Effectivity will be tested and studied in order to see the analysis and evaluation from different countries that has been integrating CCS in WtE plants before practiced in ASEAN.

To be able to accomplish such goals, the research compiles data regarding the usageof CCS and Waste to Energy plants in different countries, to compare the effectivity of the technology, authors also discuss the economic viability this technology holds, and conclude whether the technology is able to be implemented in nowaday's ASEAN.

\section{Literature Review}

\subsection{Carbon Dioxide Capture and Storage (CCS)}

Carbon Dioxide Capture and Storage (CCS) is a technology for capturing $\mathrm{CO}_{2}$ gas produced from a large-scale process, then transported to a storage location which can be located in the soil, in the sea, in carbonate minerals or used in industrial processes (Metzand Intergovernmental Panel On Climate Change.Working Group Iii 2005). Most $\mathrm{CO}_{2}$ gas emissions come from the combustion of fossil fuels in energy and electricity generation, industries such as iron and steel manufacturing, cement manufacturing, natural gas processing, and petroleum refining. $\mathrm{CO}_{2}$ produced by fossil fuel power plants contributes $42 \%$ of $\mathrm{CO}_{2}$ gas emissions worldwide (International Energy Agency 2016). One of the fossil fuels that is used as fuel in energy and electricity generation is coal, which is very abundant on earth. CCS technology can capture $85-95 \%$ of $\mathrm{CO}_{2}$ produced by an industry. The power generation industry using CCS technology requires 10-40\% more energy than industries that do not use CCS technology (Metz and Intergovernmental Panel On Climate Change. Working Group Iii 2005). However, the emission of gases released into the atmosphere is much smaller, making it more environmentally friendly. A comparison of plants using CCS technology and those not using can be seen in Figure 2. 
Figure 2. Comparison of plants with CCS and without CCS

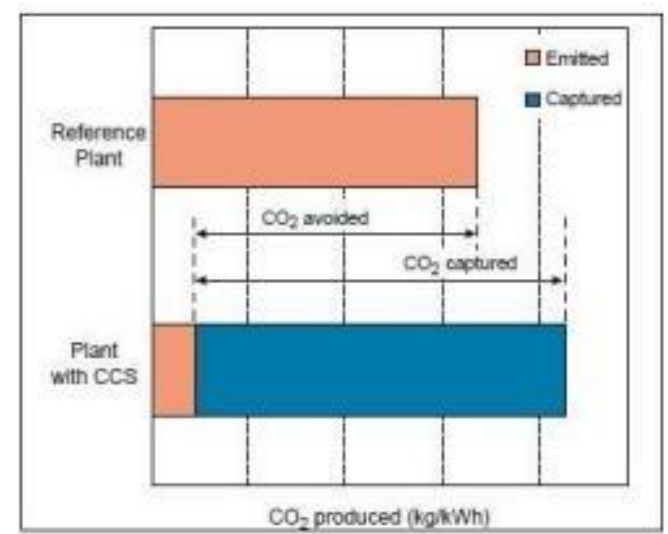

(Source: Metz and Intergovernmental Panel on Climate Change. Working Group Iii 2005)

The $\mathrm{CO}_{2}$ separation process has been widely used on an industrial scale. The $\mathrm{CO}_{2}$ is captured to produce a high pressure stream of $\mathrm{CO}_{2}$ gas that is ready to be removed. Based on the processes in the energy and electricity generation industry, there are 3 methods to capture $\mathrm{CO}_{2}$, namely post-combustion, precombustion, and oxyfuel combustion systems (Metz and Intergovernmental Panel on Climate Change. Working Group Iii 2005).

In the post-combustion method, $\mathrm{CO}_{2}$ is separated from the flue gas produced by the combustion of coal fuel by air. In general, this system uses a solvent to capture a small portion of $\mathrm{CO}_{2}$ in the flue gas with the largest fraction being nitrogen gas. In post-combustion capture systems, organic solvents such as monoethanolamine (MEA) are used (Metz and Intergovernmental Panel on Climate Change. Working Group Iii 2005).

In the pre-combustion system, the main fuel together with steam and air (oxygen) produces $\mathrm{CO}$ and $\mathrm{H}_{2}$ gases. The resulting $\mathrm{CO}$ is reacted with water vapor (water shift gas reaction) to form additional $\mathrm{H}_{2}$ and $\mathrm{CO}_{2}$. The $\mathrm{H}_{2}$ and $\mathrm{CO}_{2}$ gas mixture isthen separated, wherein the $\mathrm{CO}_{2}$ stream is captured for storage and the $\mathrm{H}_{2}$ stream is usedas fuel. Although the cost required is more expensive than the post-combustion method, the $\mathrm{CO}_{2}$ gas produced reaches $15-60 \%$ by volume on a dry basis (Metz and Intergovernmental Panel on Climate Change. Working Group Iii 2005).

In the oxyfuel combustion system, combustion is carried out using $\mathrm{O}_{2}$ so that the resulting product is a flue gas with the largest composition being $\mathrm{H}_{2} \mathrm{O}$ and $\mathrm{CO}_{2}$. The oxygen used in the combustion oxyfuel must have a purity level of $95-99 \%$ so that aunit to separate oxygen from the air is needed before the combustion process. To capture $\mathrm{CO}_{2}$ which will then be used in the CCS process, pollutants and incompressible gases such as $\mathrm{N}_{2}$ gas must be separated. The water vapor produced can be separated by cooling and compressing the gas flow. $\mathrm{CO}_{2}$ gas produced in this process has a very high concentration, which is greater than $80 \%$ by volume (Metz and Intergovernmental PanelOn Climate Change. Working Group Iii 2005). The process of capturing $\mathrm{CO}_{2}$ from the three systems above can be seen in Figure 3. 
Figure 3. CO2 Capture Process

Post combustion

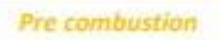

Oxyfuel

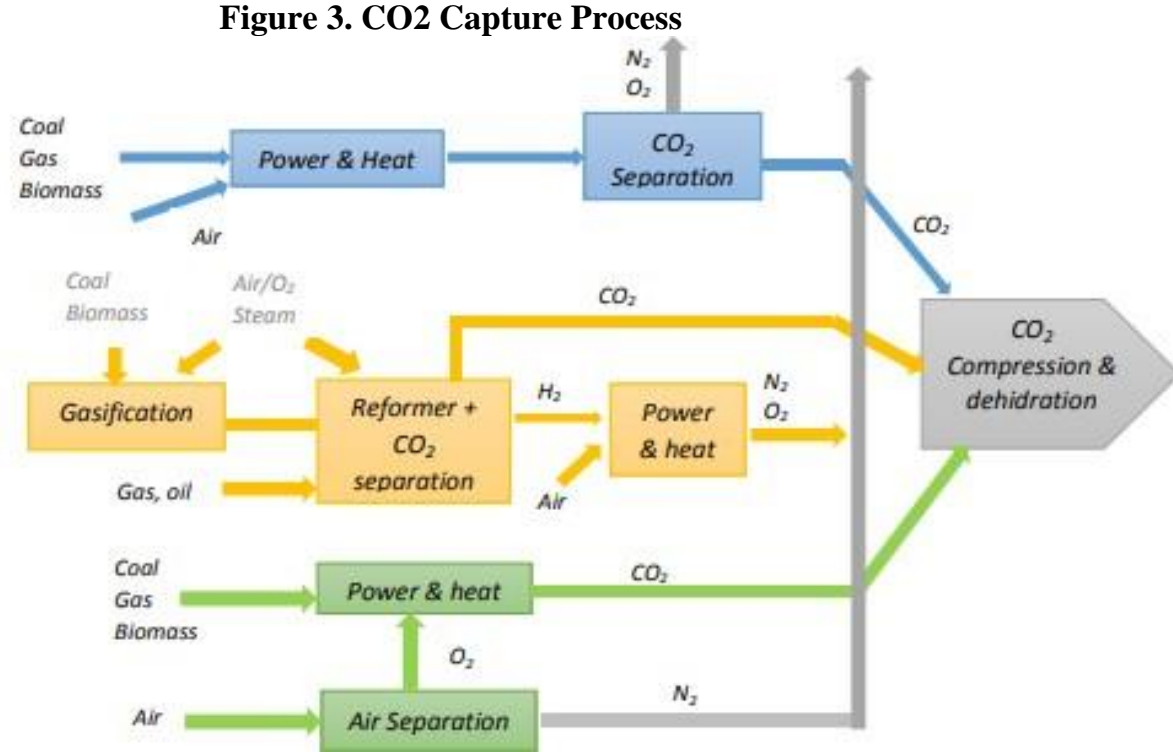

(Source: Firlina 2016)

\subsection{Waste to Energy Plants Technology}

Many options for waste management such as recycling, landfill, and utilization of waste-to-energy technology. Although landfilling has a negative impact in the form of uncontrolled release of methane gas $\left(\mathrm{CH}_{4}\right)$, it is precisely this method that is often used in waste management, especially in ASEAN region. Unlike landfills, energy recovery from waste is considered efficient, but the investment is relatively high. Most of theWtE plants are in developed countries. This waste to energy technology includes heat conversion (pyrolysis, gasification and incineration). The Waste-to-Energy process can reduce the volume of landfills, recover energy, and reduce the use of conventional fuels. In addition, waste is a cheap source of energy and can even be considered as regional income.

\section{Pyrolysis}

Pyrolysis is a process of thermochemical decomposition of organic material,which takes place without air or oxygen. Biomass pyrolysis generally takes place in a temperature range of $300^{\circ} \mathrm{C}$ to $600^{\circ} \mathrm{C}$ (Basu and Kaushal 2009). The product of this pyrolysis process depends on several factors including pyrolysis temperature and heating rate. In general, pyrolysis products can be classified into three types, namely:

1. Solid products: in the form of solid residues that are rich in carbon (char) content

2. Liquid products: in the form of (tar, hydrocarbons, and water)

3. Gaseous products $\left(\mathrm{CO}, \mathrm{H}_{2} \mathrm{O}, \mathrm{CO}_{2}, \mathrm{C}_{2} \mathrm{H}_{2}, \mathrm{C}_{2} \mathrm{H}_{4}, \mathrm{C}_{2} \mathrm{H}_{6}, \mathrm{C}_{6} \mathrm{H}_{6}\right.$ etc.).

Combustion is a chemical reaction between fuel and oxidizer (air or oxygen) which produces heat and light. This combustion process can take place if there is: fuel,oxidizer (air / oxygen) and heat or activation energy. The process of burning biomass involves a number of complex physical and chemical aspects. In general, the combustion process depends on the properties of the fuel and the combustion application. 
Figure 4. Differences in Pyrolysis, Combustion, and Gasification

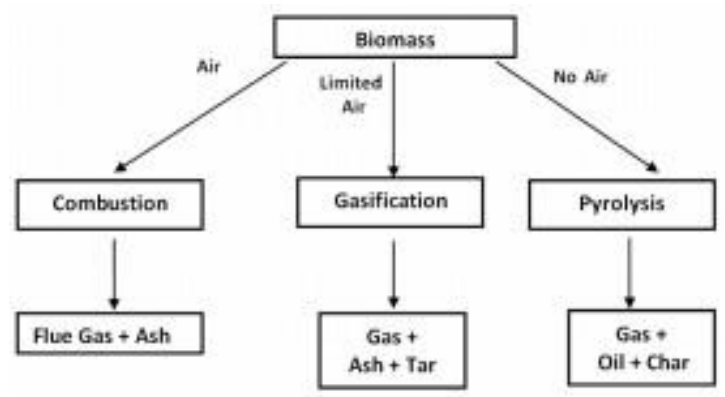

(Source: Basu 2010)

\section{Gasification Gasification}

Technology is a form of increasing the use of energy contained in biomass through conversion from solid to gas, using the material-thermal degradation process. Organic material at high temperatures in incomplete combustion. This process takes place in a device called a reactor / gasifier, biomass fuel is entered into the reactor to be burned imperfectly. In other words, the gasification process is a process of partial solid fuel combustion, involving the reaction between oxygen and solid fuel. The results of combustion in the form of water vapor and carbon dioxide are reduced to flammable gases, the gas resulting from this gasification process is called a producer gas. Generally, the content of producer gases, namely carbon monoxide $(\mathrm{CO})$, hydrogen $\left(\mathrm{H}_{2}\right)$ and methane $\left(\mathrm{CH}_{4}\right)$, can be used as a substitute for fuel oil for various purposes such as driving propulsion engines (diesel and gasoline), which can then be used as a substitute for fuel oil for various purposes. Used for power generation, driving pumps, grinding machines and others.

\subsubsection{Type of Gasification Reactor}

To carry out gasification, a reactor called a gasifier is needed. In the gasification process in the reactor / gasifier, it is required that the gasification medium which is commonly used is silica sand. Gasifiers are divided into three types based on the contact between the fuel and the gasifying media in the gasification process in the gasifier, namely: fixed / moving bed, entrained bed and fluidized bed.

1. Fixed / Moving Bed Gasifier This

Type of gasifier is the oldest and simplest type, and is only used for small scale applications. Included in this type are updraftgasifier, downdraft gasifier and crossdraft gasifier as shown in Figure 4 below. The updraft gasifier type is generally used for coal gasification. Solid fuel is introduced into the reactor from thetop and air enters the reactor from the bottom, while the resulting gas leaves the reactor at the top. At the top of the reactor there is heating and pyrolysis of the reactor fuel due to heat transfer due to forced convection and radiation from the zone below. Tar fromthe process is carried away by the gas, while the ash is removed through the bottom of the reactor. Downdraft gasifier is widely used for biomass gasification, where fuel enters the reactor from the top and air enters the combustion area. Gas and fuel flow downward and the temperature increases downward in the combustion zone. The gas produced exits the reactor at the top, the Tar content in the gas is relatively smaller when compared to the updraft type. In the crossdraft gasifier, fuel is introduced into the reactor from the top, and 
air is injected through the nozzleinto the reactor on the side, while the resulting gas is released on the side of the reactor wall in a position opposite to the air inlet.

Figure 5. (a) Updraft Gasifier, (b) Downdraft Gasifier, (c) CrossdraftGasifier

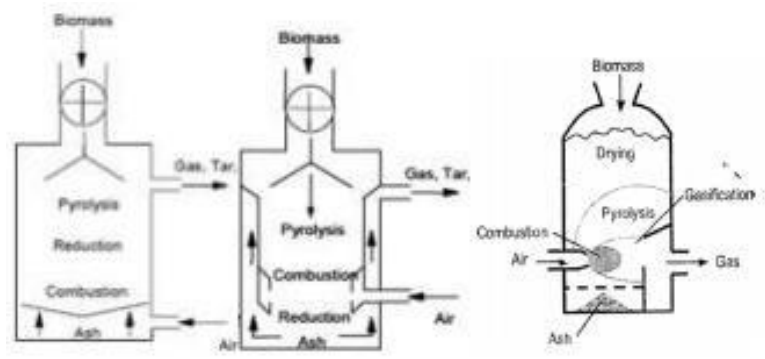

(a)

(b)

(c)

(Source: Basu 2010)

2. Entrained-FlowBed Gasifier

In this reactor, the fuel in the form of powder is mixed with air before being put into the reactor, the working temperature of the reactor is sufficient $>1000^{\circ} \mathrm{C}$ so that almost all the fuel can be converted to gas.

Figure 6. Entrained-FlowBed Gasifier

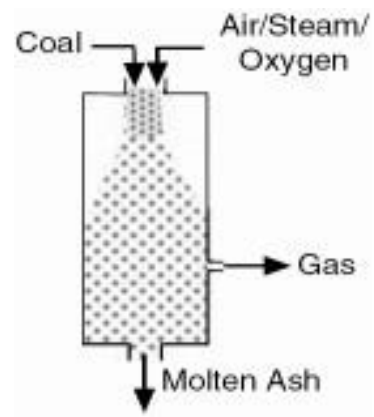

(Source: Basu 2010)

\section{Fluidized Bed Gasifier}

This type of reactor is a design approach to the problems commonly encountered in the use of updraft and downdraft type reactors, namely the absence of flow, dregs and extreme pressure drops in the reactor. Air is exhaled through the bed material at a certain speed to maintain under certain conditions. The bed material basically experiences heating from the outside and the fuel is touched so that it reaches a high temperature. Silica sand isgenerally used as a bed material, and the bed material functions as a gasification medium during the gasification process. The fuelis inserted at the bottom of the reactor, then mixed and heated by the gasification medium so that pyrolysis occurs quickly to produce a component of the mixture, mostly in the form of gas. Then gasification and tar conversion take place in the gas stage. The ash from the combustion will be carried with the gas to the reactor outlet at the top. When viewed from the contact process between the booster gas and fuel particles, Fluidized Bed gasifier (FBG) can be divided into two types, namely: Bubbling FluidizedBed Gasifier (BFBG) and Circulating 
Fluidized Bed Gasifier (CFBG). In its use, $\mathrm{CFBG}$ is superior to BFBG, this is due to the presence of a circulation channel which causes the fuel residence time in the gasifier to be longer so that it allows the fuel to be converted more completely. In addition, the required air rate for CFBG $(4-7 \mathrm{~m} / \mathrm{s})$ is greater than that for BFBG $(1-1.5 \mathrm{~m} / \mathrm{s})$,so that mass mixing and heat transfer are better.

\subsubsection{Incinerator}

Incinerator is a furnace for treating solid waste, which converts solid matter(garbage) into gaseous matter, and ash, (bottom ash and fly ash). Incineration is a process of treating solid waste by burning at temperatures of more than $800^{\circ} \mathrm{C}$ to reducecombustible waste that can no longer be recycled, killing bacteria, viruses, and toxic chemicals (Dastjerdi et al. 2019). States that the incinerator is a device used for the process of burning waste. This tool functions to change the form of waste to be smaller and more practical and produce sterile combustion residues so that it can be disposed of directly on the ground. The heat energy from combustion in the incinerator can be usedas alternative energy for other processes such as heating or drying.

Designing a waste burner requires several considerations to be considered, namelythe amount of combustion air, the remaining combustion products and the design of the incinerator. There are two types of incinerators based on the combustion method that takes place in these tools, namely the continuous type and batch type. In the continuous type of burner, the waste is added continuously with a fixed rate, while in the batch typeof incinerator, the waste is put in until it reaches the maximum limit and then it is burned together.

Currently the development of incinerator integration with CCS is in several areas such as the Netherlands and Japan. For example, in Japan it is able to capture 10 tons of carbon dioxide per day, while in the Netherlands, the $\mathrm{WtE}$ Plant integrated by applying CCS technology is able to capture 60,000 tons of $\mathrm{CO}_{2}$ per day. It is planned that at a later date the Netherlands will target 800,000 tonnes a year and rather use it in the chemical industry for plastics and biofuel production. Based on the example above, the implementation of CCS technology can successfully reduce carbon emissions from combustion residues. So far, the incinerator based on waste materials uses the post- combustion method. Moreover, this method is relatively easy to implement.

\section{Results and Discussions}

\subsection{Type of Research}

The approach used in this research is a qualitative descriptive method. The author collects and describes the industrial process of waste-to-energy plants, the effectiveness of using carbon capture storage in reducing carbon emissions and the potential for implementing carbon capture storage in the waste-to-energy process in ASEAN, especially in Indonesia. In conducting this research, we also conduct empirical research that discusses and analyzes the waste-to-energy industry in Indonesia. The data collection technique that the writer uses to collect data from various reference sources is the documentation technique. Documentation techniques are techniques used to collect documents and data needed in research problems which are then studied in depth so that they can support and increase confidence and prove an incident. In addition, due to limited time and material related to this study, the authors use literature review and research articles, from journals and online news which aim to make conclusions and evaluations on the problems that the author is studying. 


\subsection{Subject, Time, and Place of Research}

The subject of this research is a waste-to-energy plant processing project in ASEAN, especially in Indonesia, which the author has observed based on research articles, as well as research journals. The length of the research was carried out from mid-November 2020 to April 2021. The research base was conducted in Yogyakarta by observing and analyzing the industrial processes of waste-to-energy plants in Indonesia, especially in Surabaya as well as the effectiveness of the use of carbon capture storage which has been applied in several countries and the potential implementing the use of integrated carbon capture storage with the waste-to-energy plant process in Indonesiathrough government policies and economic conditions in Indonesia.

\subsection{Research Method}

The research method used is descriptive qualitative method, using secondary data sources from research results, references and online news that are directly related tothis research. Nawawi and Martini (1994: 73) define a descriptive method as a method that describes an objective state or certain event based on visible or appropriate facts which are then accompanied by efforts to draw general conclusions based on these historical facts. Descriptive research is carried out using research conducted by describing the actual properties and circumstances of the research object. The descriptive method was chosen because the research carried out was related to ongoing events and with regard to current conditions. The qualitative method with the descriptive study approach used in this study, as expressed by Sugiyono, (2012: 3 ) is a qualitative method for obtaining in-depth data and data that contains meaning. Qualitative methods can significantly influence the substance of the research. This means that the qualitative method directly presents the nature of the relationship between the researcher and the informant, the object and the research subject. Qualitative data is data that is collected based on ways that see the process or object of research. This kind of data looks more at the process than the result because it is based on a description of the process and not a mathematical calculation.

\subsection{Data Analysis Method}

The data analysis method is in the form of secondary data in the form of qualitative and quantitative data from journals and online news. Secondary data is data that refersto information collected from existing sources, obtained from research results, references and online news to support the primary information that has been obtained. Secondary data sources are those related to research, for further analysis and conclusions can be drawn. In this study, secondary data were obtained from journal documents, organizations, institutions, companies or parties related to this research. In analyzing the data, the author uses qualitative descriptive data, namely by collecting, processing and interpreting what is obtained so that it provides correct and complete information for solving the problems faced.

\section{Results and Discussions}

\subsection{Comparison of CCS Technologies}

CCS technology has several types that can be applied in power plants or industries. These technologies have differences in the mechanism of capturing carbon. Basically, we need to consider the use of CCS technology to make it more effective both from a technical and 
non-technical point of view. This is because the use of this technology requires additional costs and energy so that it must be considered carefully. The typesof CCS technology are chemical absorption technology, physical absorption technology, membrane technology, adsorption process, low-temperature systems, and mineral carbonation technology. Therefore, it is necessary to make a comparison between these technologies to find out which technology is the most effective and profitable.

The first technology is chemical absorption technology. This technology is suitable to be applied to gas streams with low concentrations. Besides, the advantages of this technology include technology that has been widely applied can filter $\mathrm{CO}_{2}$ up to $95 \%$, and solvent can generate. While the shortcomings of this technology are that the energyrequired for the solvent regeneration process is quite large and requires $20 \%$ to $30 \%$ of the total energy output of a $500 \mathrm{MW}$ power plant for capturing $\mathrm{CO}_{2}$ through chemical absorption. Then, capturing up to $95 \% \mathrm{CO}_{2}$ is proportional to the need for largeamounts of solvent and limited absorption capacity. From an economic view, the absorber and stripper section requires high capital. The second technology is physical absorption technology. This technology is commonly used and requires less energythan chemical absorption to regenerate solvent. Meanwhile, the disadvantage of this technology is that it is only suitable for high-pressure gas streams. From an economic point of view, the physical solvent is quite expensive and the absorber, stripper, and solvent section require high capital costs.

The third technology is membrane technology. This technology is suitable for highpressure gas streams with low concentrations. While the drawback is that between the two phases requires a high-pressure differential. From an economic point of view, membrane filters, compressors, membrane housing require high costs. The fourth technology is LowTemperature Systems. This technology is most suitable for binary gas streams and relatively high $\mathrm{CO}_{2}$ capture. Also, the $\mathrm{CO}_{2}$ is separated into liquid formso that it can be transported directly because it does not require compression. While thedisadvantage of this technology is that the efficiency value depends on other gas components in the smoke stream and before cryogenic separation, Traces elements of flue gases such as water vapor or methane must be removed. From an economic pointof view, distillation and refrigeration units require large costs. The fifth technology is mineral carbonation technology, this technology is exothermic and its byproducts are valuable. W hile the drawback is that the pre-treatment requires a large amount ofenergy

Based on the description above, almost all technologies require large costs so that we can put aside economic considerations first. So when viewed from its benefits, CCS technology that has the greatest positive impact is physical absorption technology and chemical absorption technology. This is because both of these technologies have high effectiveness compared to other technologies and are also capable of regenerating solvents. Then, the weaknesses of the two technologies equate to a good ability to capture $\mathrm{CO}_{2}$. Meanwhile, other technologies have advantages that have less of animpact and the disadvantages are not comparable to their advantages.

\subsection{Implementation CCS Technology for Waste to Energy}

In general, $\mathrm{WtE}$ has three processes, namely pyrolysis, gasification, and incineration. Pyrolysis is a process of thermochemical decomposition of organic material, which takes place without air or oxygen. Biomass pyrolysis generally takes place in a temperature range of $300^{\circ} \mathrm{C}$ to $600^{\circ} \mathrm{C}$ (Basu and Kaushal 2009). Gasification technology is a form of increasing the use of energy contained in biomass through conversion from solid to gas, using the material-thermal degradation process. Organic material at high temperatures in incomplete combustion. An incinerator is a furnace for treating solid waste, which converts solid matter 
(garbage) into the gaseous matter, and ash, (bottom ash and fly ash). Incineration is a process of treating solid waste by burning at temperatures of more than $800^{\circ} \mathrm{C}$ to reduce combustible waste that can no longer be recycled, killing bacteria, viruses, and toxic chemicals (Dastjerdi et al. 2019).

Based on this explanation, the three of them use the same thermal decomposition and produce $\mathrm{CO}_{2}$ emissions. However, the application of CCS as an effort to reduce emissions will be more effectively applied in the incineration process. This is because the mechanism of the incineration process is very possible if CCS is installed. Although in pyrolysis and gasification CCS technology can also be applied, incineration is more appropriate to be implemented. Given, the incineration mechanism converts waste to obtain steam which is then used to drive the turbine. So, the products from combustion and steam need to be filtered using CCS technology. For example, in Japan andNetherlands, these countries have integrated CCS technology with waste to energy. Therefore, the implementation of CCS technology is more effective and suitable for theincinerator process.

Based on chapter 4.1, physical absorption technology and chemical absorption technology are the most effective CCS technology. This is because it can capture $\mathrm{CO}_{2}$ emissions with a high enough percentage so that the wasted gas is safe. Then, the implementation of CCS on WtE can use both of these technologies as CCS technology in WtE with the incineration process. This is to support $\mathrm{WtE}$ to be more effective and environmentally friendly.

\subsection{Design Waste to Energy}

In general, waste to energy with an incineration mechanism uses an ordinary filterto filter the emissions produced by the combustion process. It is still rare to find waste to energy using CCS technology at the WTE Plant. Even though as we know, the application of CCS to this WTE plant can make it more environmentally friendly and more profitable when compared to the usual filtration process. The discussion of whether it is possible to apply CCS to a WTE plant will be discussed in this section. But beforehand it is necessary to know in advance how the design of the WTE plant is commonly used. The following is the design of the WTE plant found in most WTE plants.

Figure 7. Implementation WtE Technology Based on Incineration

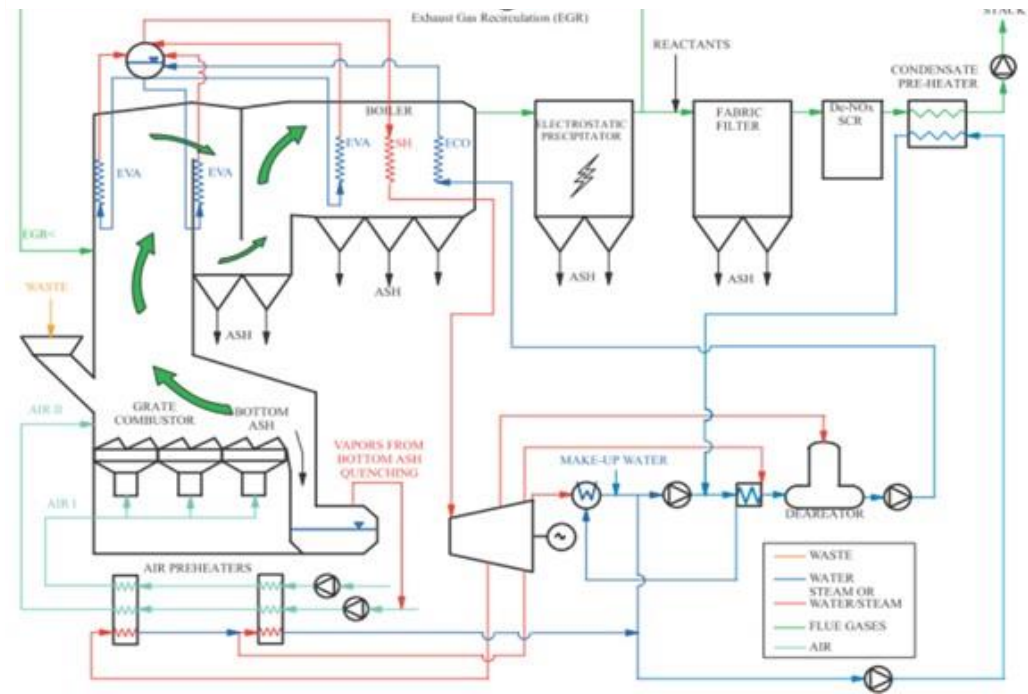

(Source: BPSDM 2019) 
Based on the picture above, waste burning occurs by producing high-temperature exhaust gases and ash. The exhaust gas is used for heat recovery in the boiler to produce hot steam for the turbine which generates electricity. The exhaust gas that has passed through the boiler then passes through the air pollution control system or the handling of flue gas so that it comes out of the chimney in a clean state. In this process, the air pollution control system uses several technologies to filter exhaust gases such asfilter fabric. The way this filter fabric works is quite simple, namely, the exhaust gas passes through the compressed air or mechanical shaker so that clean air and dust can be separated.

Detailed of Fabric Filter Process:

Figure 8. Fabric Filter Process

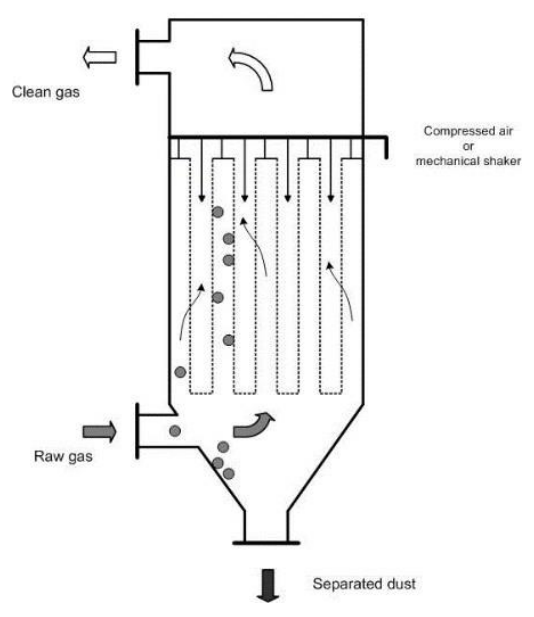

(Source: BPSDM 2019)

If the filter fabric is replaced by CCS technology, for example, physical absorption technology, and chemical absorption technology, it will be possible to apply. This is because the mechanism of CCS technology is the same but the results of capturing $\mathrm{CO}_{2}$ can be better. The thing that distinguishes each technology is its $\mathrm{CO}_{2}$ capture process, and this $\mathrm{CCS}$ technology is proven to have excellent $\mathrm{CO}_{2}$ capture capabilities. If CCS technology has been applied to the WtE plant, the captured $\mathrm{CO}_{2}$ can be stored below theearth's surface (injected under the solid rock layer) or 14ransferred into the deep ocean or can be utilized through other processes for other purposes. That is following the working principle of CCS.

In Indonesia, CCS technology has begun to be recognized and will be applied to power plants to help reduce carbon emissions. The scenario for implementing CCS that has been made in Indonesia is at one of the coal-fired power plants in the West Javaarea for 2000MW of host power plant capacity. Even though the application of the CCS in the coal-fired power plants, if applied to the WtE plant, it can also be implemented and the results will also be the same. This is because the mechanism of the coal-fired power plants and WtE Plant is almost the same and the WtE Plant also produces carbon emissions. The following is a scenario for the assessment of CCS on the West Java power plant. 
Figure 9. Scenarios of CCS Technology

\begin{tabular}{l|l|c|c|c|c|} 
& No capture & $\mathbf{9 0} \%$ capture & $\mathbf{4 5 \%}$ capture & $\mathbf{2 2 . 5 \%}$ capture \\
\hline Electricity output - MWe ${ }^{[1]}$ & 2000 & 1449 & 1723 & 1862 \\
\hline $\mathrm{CO}_{2}$ captured - $\mathrm{t} / \mathrm{hr}^{[2]}$ & 0 & 1558.8 & 779.4 & 389.7 \\
\hline $\mathrm{CO}_{2}$ discharged to air - t/hr & 1,732 & 173.2 & 952.6 & 1342.3 \\
\hline $\begin{array}{l}\text { Fraction of power plant flue gas } \\
\text { sent to } \mathrm{CO}_{2} \text { capture }\end{array}$ & $0 \%$ & $100 \%$ & $50 \%$ & $25 \%$ \\
\hline $\mathrm{CO}_{2}$ emission - kg/MWh ${ }^{[3]}$ & 866 & 119 & 553 & 721 \\
\hline $\mathrm{Number}^{[3} \mathrm{MEA}$ trains & 0 & 12 & 6 & 3 \\
\hline $\begin{array}{l}\text { Annual } \mathrm{CO}_{2} \text { storage at } 80 \% \\
\text { capacity factor - million tonnes }\end{array}$ & 0 & 10.92 & 5.46 & 2.73 \\
\hline $\begin{array}{l}\text { Notes: } \\
\text { Megawatt hour. }\end{array}$ & & & & \\
\hline
\end{tabular}

(Source: Johari et al. 2012)

Based on the table, using CCS with a $90 \%$ capture scenario, $\mathrm{CO}_{2}$ discharge to air is only 173.2 tonnes per hour which are compared to "no capture" of 1732 tonnes per hour. This number is very significant in reducing carbon emissions. However, when compared to $22.5 \%$ of the capture scenario, the $\mathrm{CO}_{2}$ discharge to air is 1342.3 tonnes per hour, although there is not much difference, the captured $\mathrm{CO}_{2}$ can reach 389.7 tonnes per hour, which is "no capture" does not exist at all. Also, the table aboveclearly shows that the use of ccs is effective in capturing $\mathrm{CO}_{2}$ even though at $22.5 \%$ of the capture scenario there are still differences both from $\mathrm{CO}_{2}$ captures, $\mathrm{CO}_{2}$ discharged to air, Fraction of power plant flue gas sent to $\mathrm{CO}_{2}$ capture, Number of MEA trains and Annual $\mathrm{CO}_{2}$ storage at $80 \%$ capacity factor.

\subsection{Workflow System of Waste to Energy Plant}

The working method of the WtE plant itself has four stages, namely pre-treatment, combustion, Heat recovery, and Flue Gas Treatment or Air Pollution Control. In the pretreatment, the waste is sorted, mixed, or shredding. Furthermore, the combustion process following the $3 \mathrm{~T}$ aspects (temperature, turbulence, time) where the higher the temperature, the increasing turbulence, and the longer the residence time of flue gasand waste, the combustion process goes well. Then, heat transfer is the process of utilizing heat from flue gas using the principle of heat transfer. After this process, the heat from the flue gas can be used as electrical energy through turbines and generators. Flue gas that has gone through this process must then go through Air Pollution Control or Flue Gas Treatment, which have many technological options and aim to make the emission out within safe limits. The following is a system workflow from the $\mathrm{WtE}$ plant with the incineration process.

Figure 10. Workflow System of WtE Plant with IncinerationProcess

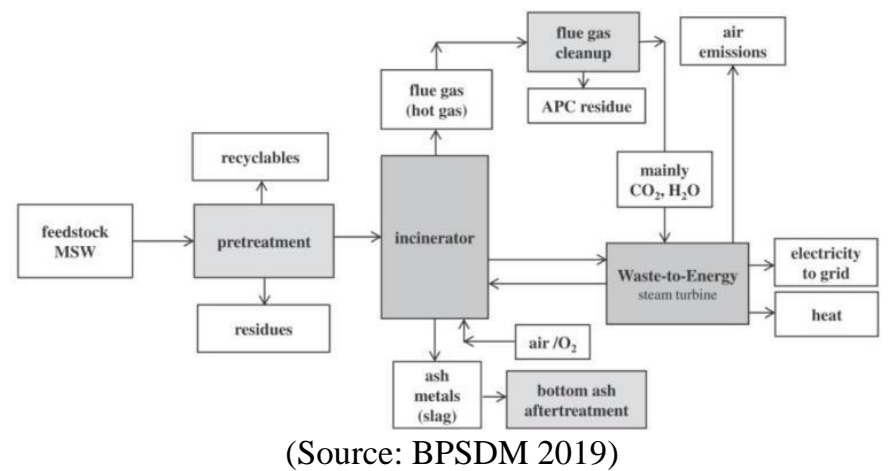


Based on the figure, the process from pre-treatment to incineration is explained as previously mentioned. The Waste-to-Energy section shows that a heat transfer occursto the steam turbine to produce electricity or heat. The picture also shows several processes for Air Pollution Control or Flue Gas Treatment, where various technologies are used to treat various types of waste, both air and solid. However, the author wantsto clarify the Air Pollution Control process which is the concentration in this article. In WtE, CCS technology will be applied as a substitute for the technology contained in the workflow above. The following is a workflow system from CCS technology.

Figure 11. Workflow system from CCS Technology

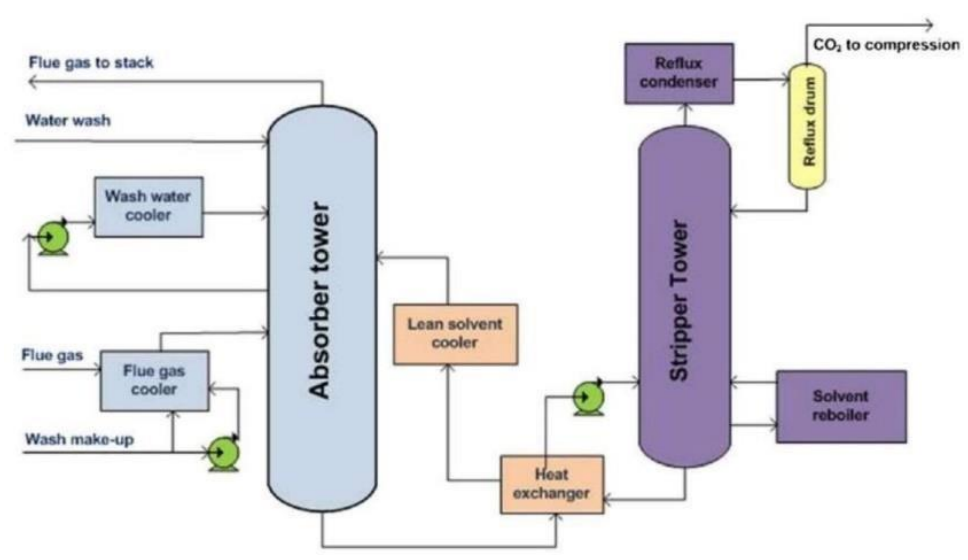

(Source: Sabouni R, Kazemian H, Rohani S 2013)

The mechanism CCS technology is actually "Capturing" which means separating and purifying $\mathrm{CO}_{2}$ from the remaining exhaust gas that has passed through the boiler. Solventbased $\mathrm{CO}_{2}$ capture (absorption) is most suitable for WtE applications. That isas shown in the picture above, which uses absorption and stripper, which is part of the mechanism in chemical absorption technology and physical absorption technology. The solvent used is usually in the form of aqueous amine solutions such as monoethanolamine (MDEA), monoethanolamine (MEA), or proprietary solvents. Furthermore, in the regeneration solvent process (stripper reboiler) energy input is required - electricity which functions for the pump and steam. Apart from downstream, it transports either solid (> 74 bar) or liquid phases, both of which require electricity for $\mathrm{CO}_{2}$ compression or cooling. Thus, the implementation of CCS technology in the $\mathrm{WtE}$ plant is very possible and can produce enormous benefits.

\subsection{Policy for Waste to Energy and CCS}

Indonesia is one of the countries that is accelerating the construction of waste to energy plants. This can be seen from the Indonesian government which made Presidential Regulation No. 35 of 2018 concerning the acceleration of the construction of waste processing installations into electric energy based on environmentally friendly technology. The regulation also refers to the previous regulation, namely Article 4 of Law Number 18 of 2008 concerning Waste Management, and to reduce the volume of waste significantly for the sake of cleanliness and beauty of the city, it is deemed necessary to accelerate the construction of an installation of Waste Processing into Electric Energy Based on Environmentally Friendly Technology in the regions. Certain provinces and cities. Based on the regulations that have been made, it shows that the government fully supports the construction of a WtE plant. Also, 
in the presidential regulation, many things have been regulated, such as cities targeted for development, licensing, funding, and other regulations that support the acceleration of waste toenergy plant development.

For regulations regarding CCS in Indonesia, several things need to be considered regarding this technology. CCS is a technology that is still in its early stages inIndonesia, so it needs to be implemented on a small scale first then on a large or commercial scale. Besides, this CCS requires three stages of the process, namelycapture, transportation, and storage. This causes the implementation of CCS to be able to successfully run all three, starting from capturing $\mathrm{CO}_{2}$ in power plants (in this case the $\mathrm{WtE}$ plant), then transportation if storage is carried out underground. Therefore, an appropriate regulatory and institutional framework is needed, this can be seen in the chart below.

Figure 12. Indonesia's Government Policy of CCS Technology

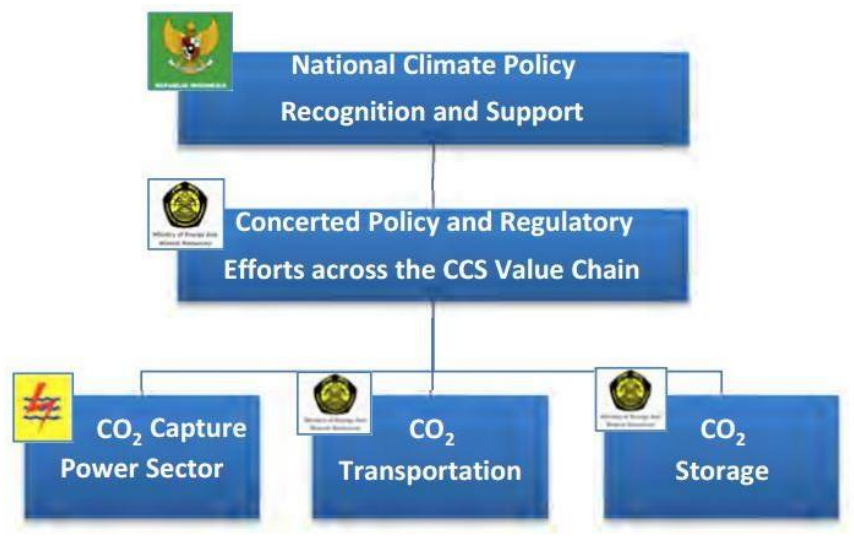

(Source: World Bank 2015)

\subsection{Economic Consideration}

The construction of a WtE plant is one of the ways to achieve sustainable development goals, namely investment in sustainable energy, which is one of the efforts to reduce climate change. From an economic point of view, the WtE plant has the potential to provide benefits that can be obtained from sales and carbon credits. For example in Malaysia, the country in 2020 methane gas emissions of 370,000 tonnes, which is equivalent to 7,770,000 CO2. This amount can provide a profit of RM 307,692,000 as a result of carbon credit if captured and used in a Clean Development Mechanism (CDM) project or another renewable energy scheme. In that year, Malaysia can also get revenue from the electricity sale of RM $690,000,000$ with the equivalent electricity generation of $2.3 \times 10^{9} \mathrm{kWh}$. Based on this, the WtE plant can certainly provide a decent profit if processing from start to finish can be done well.

\section{Conclusions and Recommendations}

CCS integrated Waste To Energy plants is a technology for the future of ASEAN, showing prospects of reduce carbon negative emission. Even though the capital cost will be higher than conventional energy plants, the technology will be able to solve two of ASEAN most invasive issues. A number of developments is needed in these particular fundamentals of the technology.

1. Financial Aspects

From our calculations in the study, it is shown that the capital cost of developing 
aneffective technology of CCS integrated $\mathrm{WtE}$ will be higher, and impacting on higher cost of electricity generation as well. In order to lower the cost of developing an integration of these tho technology, a few things are need to be done. A further more specific analysis of economic and finance in a potential region, because each and every regions might have different financial profiles. A complete economic analysis of amine-based chemical absorption on WtE facilities, including detailed modelling, calculations, and sensitivity analysis.

2. A Study on the use of CCUS technology in WtE plants.

From previous studies, there hasn't been much success in developing Carbon Capture Utilization and Storage in WtE plants developments. The technology will also holds a significant role in future energy developments if done effectively.

3. Government Policy on WtE plants and Carbon Capture Technology

Proactively engange Government to support on WtE plants and Carbon Capture technology to accelerate development on it. Government also can offer a financial assistance to a industry who wants built integration between $\mathrm{WtE}$ plants and CarbonCapture technology. 


\section{BIBLIOGRAPHY}

\section{Books}

International Energy Agency. (2016). CO2 Emissions From Fuel Combustion Highlights, edition 2016. France: International Energy Agency.

International Energy Agency. (2020). Waste-to-energy (Municipal Solid Waste). France:International Energy Agency.

Metz, Bert, and Intergovernmental Panel On Climate Change. Working Group Iii. 2005.IPCC Special Report on Carbon Dioxide Capture and Storage. New York: Cambridge University Press.

Prabir Basu. 2010. Biomass Gasification and Pyrolysis: Practical Design and Theory. Burlington, Ma: Academic Press.

\section{Journals and Articles}

Basu, Prabir, and Priyanka Kaushal. 2009. "Modeling of Pyrolysis and Gasification of Biomass in Fluidized Beds: A Review." Chemical Product and Process Modeling 4 (1). https://doi.org/10.2202/1934-2659.1338.

Chandel, Munish K, Gabriel Kwok, Robert B Jackson, and Lincoln F Pratson. 2012. "The Potential of Waste-To-Energy in Reducing GHG Emissions." Carbon Management 3 (2): 133-44. https://doi.org/10.4155/cmt.12.11.

Dastjerdi, B., V. Strezov, R. Kumar, and M. Behnia. 2019. "An Evaluation of the Potential of Waste to Energy Technologies for Residual Solid Waste in New South Wales, Australia." Renewable and Sustainable Energy Reviews 115 (November): 109398. https://doi.org/10.1016/j.rser.2019.109398.

Firlina, Mardika. 2016. "Utilization of Carbon Capture and Storage Technology in PLTU in Efforts to Reduce CO2 Emissions to the Atmosphere". Accessed on 8 April 2021.

Global CCS Institute. (2018). Is The World Ready for Carbon Capture and Storage? 2018.1

Johari, Anwar, Saeed Isa Ahmed, Haslenda Hashim, Habib Alkali, and Mat Ramli. 2012. "Economic and Environmental Benefits of Landfill Gas from Municipal Solid Waste in Malaysia." Renewable and Sustainable Energy Reviews 16 (5): 2907-12. https://doi.org/10.1016/j.rser.2012.02.005.

Moazzem, S., M.G. Rasul, and M.M.K. Kh. 2012. "A Review on Technologies for Reducing CO2 Emission from Coal Fired Power Plants." Thermal Power Plants, January. https://doi.org/10.5772/31876.

Sabouni R, Kazemian H, Rohani S. Carbon dioxide capturing technologies: a review focusing on metal organic framework materials (MOFs). Environ Sci Pollut Res Int. 2014 Apr;21(8):5427-49. doi: 10.1007/s11356-013-2406-2. Epub 2013 Dec 15. PMID: 24338107.

\section{Websites}

“Can Waste-To-Energy Become Carbon Negative?" 2020. ESWET - European Suppliers of Waste to Energy Technology. December 5, 2020. http://www.eswet.eu/can-waste-to-energy-become-carbon negative/\#: :text=With\%20previsions\%20of\%20global\%20waste.

BPSDM.2019."Modul Pengenalan CCS Inceneration." Https Https://Bpsdm.pu.go.id/Center/Pelatihan/Uploads/Edok/2019/04/E34ac_9._Mo dul_Insinerasi.pdf. Accessed April 28, 2021 
World Bank. 2015. The Indonesia Carbon Capture Storage Capacity Building Program :CCS for Coal-fired Power Plants in Indonesia. Washington, DC. (C) World Bank. https://openknowledge.worldbank.org/handle/10986/22804 License: CC BY 3.0 IGO. 